\title{
Comparative susceptibility of representative Great Lakes fish species to the North American viral hemorrhagic septicemia virus Sublineage IVb
}

\author{
Robert Kim ${ }^{1}$, Mohamed Faisal ${ }^{1,2,3, *}$ \\ ${ }^{1}$ Comparative Medicine and Integrative Biology Program, ${ }^{2} \mathrm{~S}-110$ Plant Biology Building, Department of Pathobiology \\ \& Diagnostic Investigation, College of Veterinary Medicine, and ${ }^{3}$ Department of Fisheries and Wildlife, \\ College of Agriculture and Natural Resources, Michigan State University, East Lansing, Michigan 48824, USA
}

\begin{abstract}
The present study compared the susceptibility of representative Laurentian Great Lakes fish species to the emerging viral hemorrhagic septicemia virus (VHSV) Genotype IVb. The median lethal dose of infection by intraperitoneal injection (IP-LD ${ }_{50}$ ) was obtained from fish that were experimentally infected with the MI03 index strain of VHSV-IVb. Fish were injected at doses ranging from $7 \times 10^{7}$ to $7 \times 10^{-2}$ plaque-forming units (pfu) and maintained at $12 \pm 1^{\circ} \mathrm{C}$. The infection trials identified species of high, medium, and low susceptibility based on the IP-LD 50 values. Pathogenicity of VHSV-IVb was highest in largemouth bass Micropterus salmoides, which resulted in an IP-LD 50 of $1.5 \times 10^{2} \mathrm{pfu}$, while also demonstrating the clinical diathesis of VHSV-infected fish. The virus was moderately pathogenic in yellow perch Perca flavescens (IP-LD ${ }_{50}$ of $2.5 \times 10^{5} \mathrm{pfu}$ ), but also showed the classical signs of VHSV infection. Salmonids were the least susceptible to VHSV-IVb with IP-LD 50 values of no less than $1.4 \times 10^{6} \mathrm{pfu}$; however, in fish that succumbed to infection, characteristic VHSV lesions were observed. Histopathologic alterations were most profound in gill, skin, muscle, gonads, and liver of largemouth bass and yellow perch, while in salmonids, hemorrhages in the swimbladder and/or degenerative changes in the liver were the most common lesions noticed. VHSV was isolated from infected fish, and its identity was confirmed by the reverse transcriptase polymerase chain reaction. These results highlight the variations among fish species susceptibility to this emerging strain of VHSV and offer insights into the potential impact of VHSV-IVb on the Laurentian Great Lakes fish community.
\end{abstract}

KEY WORDS: Susceptibility · Viral hemorrhagic septicemia virus · Genotype IVb · Host range · Great Lakes $\cdot$ Experimental infection $\cdot$ Rhabdovirus

\section{INTRODUCTION}

Viral hemorrhagic septicemia (VHS) is a serious viral infection of teleosts in the northern hemisphere (Wolf 1988). The causative agent is the viral hemorrhagic septicemia virus (VHSV), a member of the genus Novirhabdovirus in the family Rhabdoviridae (Tordo et al. 2005). Since the initial description of VHS by Schäperclaus (1938) and virus isolation by Jensen (1963) on cell culture, the disease has spread into many European countries devastating rainbow trout Oncorhynchus mykiss farmed in freshwater.
Nearly 3 decades later, VHSV was identified in North America for the first time in coho salmon Oncorhynchus kisutch (Hopper 1989) and chinook salmon O. tshawytscha (Brunson et al. 1989). Subsequent isolations in other marine fish were soon reported in Europe (Dixon et al. 1997, Mortensen et al. 1999, Smail 2000) and North America (Meyers et al. 1992, 1999, Traxler et al. 1995, Benmansour et al. 1997, Hedrick et al. 2003). VHSV was later isolated in water around Japan (Byon et al. 2006) and Korea (Kim et al. 2003). Such isolations strongly suggest that VHSV may be endemic to the marine environment. 
Based upon partial sequences of the $\mathrm{G}$ and $\mathrm{N}$ genes and phylogenetic analyses of VHSV isolates worldwide, 4 distinct genotypes of VHSV (designated I to IV) have been identified (Snow et al. 1999, 2004, EinerJensen et al. 2004, 2005). Each of these genotypes has its geographic and host ranges. Genotype I consists of 5 subgroups and is the major cause of VHS epidemics in European rainbow trout farms, but also includes marine species from the Baltic Sea. Genotype II also includes a number of fish species from the Baltic Sea, while Genotype III includes marine fish species around the British Isles. Genotype IV pertains to isolates from North America, Japan, and Korea.

Most recently, a novel sublineage of the North American VHSV was found in the Laurentian Great Lakes basin and has been linked to numerous massive kills of freshwater fish species such as the muskellunge Esox masquinongy (Elsayed et al. 2006), freshwater drum Aplodinotus grunniens (Lumsden et al. 2007), round gobies Neogobius melanostomus (Groocock et al. 2007), striped bass Morone saxatilis, brown trout Salmo trutta trutta, mummichog Fundulus heteroclitus, and 3-spined stickleback Gasterosteus aculeatus aculeatus (Gagné et al. 2007). Genotyping of this recent VHSV isolate from the Great Lakes has shown that it is distinct from all 4 previously known genotypes, but most closely related to the marine VHSVIVa (Elsayed et al. 2006). The Great Lakes VHSV isolates have therefore been designated as Genotype IVb. This new VHSV differs from VHSV-IVa, not only in terms of gene sequences, but also in its affinity to freshwater systems, infecting 28 fish species thus far (www.aphis.usda.gov). This presumably wide host range within a confined location has never been reported with other VHSV strains or other fish pathogenic rhabdoviruses.

In all VHSV-IVb-associated fish kill episodes, mature, large fish were the only age class noted. This has raised the question of whether or not other age classes of susceptible fish species also succumb to VHSV-IVb. While fish kill episodes demonstrate the destructive and pathogenic nature of VHSV-IVb (Gagné et al. 2007, Groocock et al. 2007, Lumsden et al. 2007), little data exist on VHSV-IVb pathogenicity to Great Lakes fish, the lesions they induce, and whether this VHSV strain is the only cause of fish kills observed in the Great Lakes basin.

In a preliminary study, 11 juvenile Great Lakes fish species were injected by the intraperitoneal (i.p.) route with VHSV-IVb at equivalent doses, which were approximately $7 \times 10^{5}$ or $7 \times 10^{4}$ plaque-forming units (pfu) (Kim \& Faisal 2010). Interestingly, the results indicated higher mortalities in muskellunge and largemouth bass, while yellow perch and a number of salmonids experienced moderate to low mortality rates at the same dose.
Despite the fact that Rivers' (1937) postulates were fulfilled in the present study, it was not clear whether variable susceptibility existed among Great Lakes fish. Comparing susceptibilities to VHSV is critical to fisheries managers as it will help guide decisions in conservation and restoration efforts. To this end, a more comprehensive study was designed, using a wider range of doses and greater numbers of fish to compare the susceptibility of juvenile fish species based on the calculated median lethal dose of infection in resident game fish of the Laurentian Great Lakes basin.

\section{MATERIALS AND METHODS}

Cell culture and virus propagation. We used the Great Lakes VHSV-IVb MI03 strain, originally isolated in our laboratory from a naturally infected muskellunge Esox masquinongy caught from Lake St. Clair (Elsayed et al. 2006). Virus stocks were produced in Epithelioma papulosum cyprini (EPC; Fijan et al. 1983), aliquoted, and kept at $-80^{\circ} \mathrm{C}$ until used. To determine the virus concentration, a plaque assay was performed on EPC cell lines by pre-treating the cells with polyethylene glycol and using a methylcellulose overlay as described in Batts \& Winton (1989) and Bates et al. (1991). Titrated virus stocks were aliquoted in cryogenic vials (Corning) and kept at $-80^{\circ} \mathrm{C}$ until used.

Cell lines were maintained and sub-cultured in $150 \mathrm{~cm}^{2}$ tissue culture flasks (Corning) at $25^{\circ} \mathrm{C}$ using a growth formulation of Earle's salt-based minimal essential medium (MEM) (Invitrogen) supplemented with $29.2 \mathrm{mg} \mathrm{ml}^{-1}$ L-glutamine (Invitrogen), penicillin (100 IU ml ${ }^{-1}$ ) and streptomycin $\left(0.1 \mathrm{mg} \mathrm{ml}^{-1}\right)$ (Invitrogen), $10 \%$ fetal bovine serum (Hyclone), and sodium bicarbonate (7.5\% w/v; Sigma-Aldrich).

Fish and maintenance. Juvenile fish from 7 species were obtained from several sources. Fingerlings of salmonid species were obtained as gametes and subsequently fertilized, incubated, and raised at the Michigan State University Research Containment Facility (East Lansing, Michigan [MI]). Gametes of coho salmon Oncorhynchus kisutch were obtained from the Platte River Weir (Beulah, MI), chinook salmon $O$. tshawytschu from the Little Manistee Weir (Stronach, MI), brown trout Salmo trutta and rainbow trout Oncorhynchus mykiss from the Oden State Fish Hatchery (Alanson, MI), and brook trout Salvelinus fontinalis from the Marquette State Fish Hatchery (Marquette, MI). Gamete samples and tissues from 5 fingerlings were tested for the presence of VHSV and other pathogens according to the guidelines of the American Fisheries Society Bluebook (2007). In addition, certified VHSV-free juvenile largemouth bass 
Micropterus salmoides were purchased from Stoney Creek Fisheries and Equipment (Grant, MI) and yellow perch Perca flavescens were purchased and transported from Cedar Lane Farms (Wooster, Ohio). Information on weights and lengths of experimental fish are given in Table 1.

Prior to infection, 5 fish from each species were euthanized using an overdose of tricaine methanesulfonate (MS-222; Argent Chemical Laboratories) (25 $\mathrm{mg} \mathrm{ml}^{-1}$ ) and tested for the presence of VHSV. Briefly, kidney and spleen were aseptically removed and homogenized using a Biomaster Stomacher (Wolf Laboratories) at the high speed setting for 2 min. Homogenates were diluted with Earle's salt-based MEM, supplemented with $12 \mathrm{mM}$ Tris buffer (Sigma), penicillin (100 IU $\left.\mathrm{ml}^{-1}\right)$, streptomycin (100 $\left.\mu \mathrm{g} \mathrm{m}^{-1}\right)$ (Invitrogen), and amphotericin B (250 $\mathrm{g} \mathrm{ml}^{-1}$, Invitrogen) to produce a 1:4 dilution (w/v) of original tissues. Samples were centrifuged at $2000 \times g$, and the supernatant was inoculated into the individual wells of a 24 -well plate containing EPC cells grown with MEM (5\% fetal bovine serum). Cultures were incubated at $15^{\circ} \mathrm{C}$ for $7 \mathrm{~d}$, and observed for the formation of the cytopathic effect (CPE). Infected cells were then placed in a $-80^{\circ} \mathrm{C}$ freezer and removed after $24 \mathrm{~h}$. The medium was removed, thawed, and centrifuged. The supernatant was inoculated for a second time onto EPC cell lines, and, after $7 \mathrm{~d}$, was assessed for the presence of VHSV by reverse transcriptase polymerase chain reaction (RT-PCR).

Experimental fish were allowed to acclimate to laboratory conditions for $3 \mathrm{wk}$, during which time the temperature was progressively lowered to $12 \pm 1^{\circ} \mathrm{C}$ before the experiment was initiated. All fish were initially held in $600 \mathrm{l}$ circular fiberglass tanks in a continuous flow-through system supplied with oxygenated and

Table 1. Species type, median lethal dose of infection, and lengths and weights of each species are presented. Species susceptibility is listed in highest to lowest in descending order based on median lethal dose of infection by intraperitoneal injection (IP- $\mathrm{LD}_{50}$, in plaque-forming units [pfu])

\begin{tabular}{|lccc|}
\hline Species & $\mathrm{IP}^{2} \mathrm{LD}_{50}(\mathrm{pfu})$ & Length $(\mathrm{cm})$ & Weight $(\mathrm{g})$ \\
\hline Cool water & & & \\
Muskellunge Esox masquinongy & & & \\
Largemouth bass & 2.21 & $15.8 \pm 1.0$ & $17.5 \pm 2.3$ \\
$\quad$ Micropterus salmoides & $1.5 \times 10^{2}$ & $17.5 \pm 1.0$ & $82.2 \pm 12.3$ \\
Yellow perch Perca flavescens & $2.5 \times 10^{5}$ & $18.3 \pm 0.2$ & $75.5 \pm 6.6$ \\
Cold water & & & \\
Rainbow trout Oncorhynchus mykiss & $1.4 \times 10^{6}$ & $13.8 \pm 0.9$ & $24.8 \pm 3.2$ \\
Brook trout Salvelinus fontinalis & $5 \times 10^{6}$ & $16.7 \pm 1.1$ & $45.2 \pm 10.1$ \\
Brown trout Salmo trutta & $5 \times 10^{6}$ & $16.9 \pm 0.7$ & $47.8 \pm 6.0$ \\
Chinook salmon Oncorhynchus & $1.01 \times 10^{7}$ & $8.9 \pm 0.4$ & $6.6 \pm 1.0$ \\
Coho salmon Oncorhynchus kisutch & $>7 \times 10^{7}$ & $16.5 \pm 1.6$ & $38.5 \pm 14.5$ \\
aMuskellunge data was obtained from a previous study (Kim \& Faisal 2010) & \\
\hline
\end{tabular}

facility-chilled well water (Michigan State UniversityResearch Containment Facility, East Lansing, MI). All fish species were fed daily at from 1.2 to $1.5 \%$ of body weight using from 2.0 to $4.0 \mathrm{~mm}$ feed (Silver Cup). Prior to their use in the experimental infection studies, all fish were acclimated to laboratory conditions and observed for normal feeding behavior.

Fish were designated as cool water (largemouth bass and yellow perch) or cold water species (rainbow trout, brook trout, brown trout, chinook salmon, coho salmon). Morbidity, mortality, and median lethal dose of infection by intraperitoneal injection (IP-LD ${ }_{50}$ ) calculation demonstrated the presence of clear variability among the 7 species tested for their susceptibility to VHSV-IVb.

Experimental infection. In this experiment, juveniles of 7 fish species were challenged with doses ranging from as high as $7 \times 10^{7}$ pfu to as low as $7 \times 10^{-2}$ pfu in $100 \mu \mathrm{l}$ MEM supplemented with $2 \%$ fetal bovine serum by i.p. injection. Each dose level was administered to 10 fish shortly after being anesthetized with MS-222 (100 to $150 \mathrm{ppm}$ ). Fish were then recovered from anesthesia in a 721 polyethylene tank (Aquatic Eco-Systems) in a continuous flow-through system. A negative control tank for each species contained 10 fish that were injected i.p. with $100 \mu \mathrm{l}$ MEM only. All fish were monitored daily for an observation period of $28 \mathrm{~d}$ post-infection (p.i.). The inflowing water was supplied by an underground well and chilled to $12 \pm 1^{\circ} \mathrm{C}$ throughout the duration of the experiment. The outflow was united into a common tract entering an ultraviolet sterilization unit (Aquafine). Tanks were monitored every 8 to $12 \mathrm{~h}$ daily for moribund or dead fish.

Virus recovery. Kidney and spleen tissues were collected from each dead or moribund fish, processed, diluted, and then tested for the presence of VHSV by the methods described above.

Histopathology. Lesions that were grossly observed from dead and severely moribund (euthanized with an overdose of MS-222; $25 \mathrm{mg} \mathrm{ml}^{-1}$ ) fish were sampled and submitted for histopathology. External and internal lesions were fixed in $10 \%$ formalin prior to sectioning. Tissue sections (5 $\mu \mathrm{m})$ were stained with hematoxylin and eosin (H\&E) as detailed in Prophet et al. (1992).

RNA extraction and RT-PCR. Total RNA was extracted from infected cells using Trizol LS Reagent (Invitrogen), according to the manufacturer's instructions. Reverse transcription was accomplished by a 2-step protocol using the Affinity Script Multiple Tem- 
perature Reverse Transcriptase RT-PCR (Stratagene) following the manufacturer's instructions. The primer set used in this assay is recommended by the World Organization for Animal Health (OIE 2006) for detection of a 811 base pair sequence of the VHSV nucleocapsid gene: 5' GGG GAC CCC AGA CTG T 3' (forward primer) and 5' TCT CTG TCA CCT TGA TCC 3' (reverse primer). PCR was achieved by adding into each reaction tube $5 \mu \mathrm{l}$ of viral RNA, $50 \mathrm{pmol}$ of each primer, $25 \mu$ of Choice Taq Mastermix DNA Polymerase (Denville Scientific), and DNAase-free water to create a final volume of $50 \mu \mathrm{l}$. The reverse transcriptase was inactivated by subjecting the mixture to a $94^{\circ} \mathrm{C}$ for $2 \mathrm{~min}$, and 30 cycles of PCR (denaturation for $30 \mathrm{~s}$ at $94^{\circ} \mathrm{C}$, annealing for $30 \mathrm{~s}$ at $52^{\circ} \mathrm{C}$, and polymerization at $68^{\circ} \mathrm{C}$ for $1 \mathrm{~min}$ ) in a Mastercycler Personal Thermal Cycler (Eppendorf). The polymerization was finalized by maintaining the mixture for a period of $7 \mathrm{~min}$ at $68^{\circ} \mathrm{C}$. The product was visualized by gel electrophoresis in $1.5 \%$ agarose gels. A subsample of each species was tested by cell culture and RT-PCR assay using VHSV-specific primers.

\section{RESULTS}

Prior to experimental infection, subsamples of experimental fish were found to be free of VHSV or any other virus that can replicate in EPC cell lines.

\section{Largemouth bass Micropterus salmoides}

The first incidence of mortality was noted as early as Day 6 p.i. at doses of $7 \times 10^{4}, 7 \times 10^{3}$, and $7 \times 10^{2} \mathrm{pfu}$ (Fig. 1). However, fish infected with $7 \times 10^{3} \mathrm{pfu}$ reached a maximum cumulative mortality of $90 \%$ by Day 27 p.i., whereas the group infected at a higher dose of $7 \times 10^{4}$ pfu reached $80 \%$ mortality by Day 16 p.i. Rapid rates of mortality were exhibited between Days 5 and 10 p.i. in fish infected with $7 \times 10^{4}$ to $7 \times$ $10^{1} \mathrm{pfu}$. Doses $\leq 7 \mathrm{pfu}$ did not result in any mortality of the fish monitored for $28 \mathrm{~d}$ p.i. The Reed \& Muench (1938) equation resulted in an IP-LD 50 dose of $1.5 \times$ $10^{2}$ pfu (Table 1$)$.

Infected fish exhibited gross lesions externally and internally that were identical in moribund and dead fish regardless of the VHSV dose. Pronounced petechiation on most fins was noted (Fig. 2a). Diffuse dermal erythema (Fig. 2b) was also appreciable on the ventral abdomen with peri-anal swelling and partial anal prolapse (Fig. 2b). Focal areas of hemorrhage were noted on gill arches surrounded by pale and whitened lamellae (Fig. 2c). In some fish, subdermal petechiation was noted caudal to the gills (Fig. 2d). Internal organs were

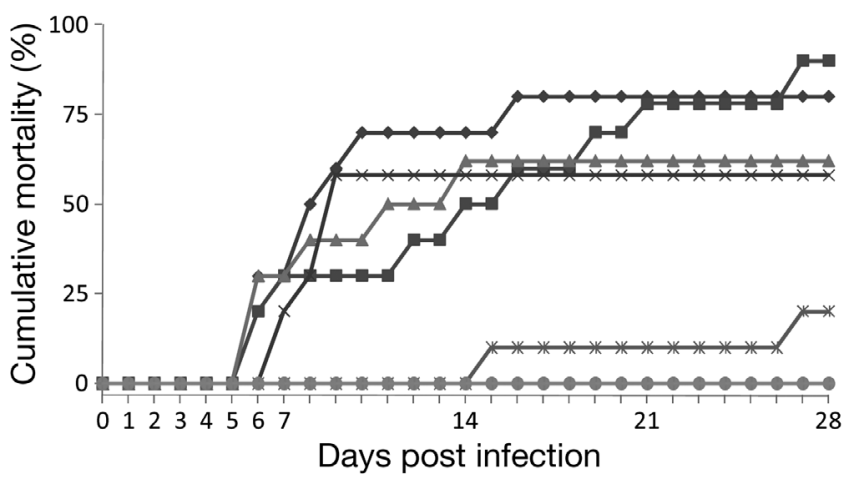

Fig. 1. Micropterus salmoides. Cumulative mortalities for largemouth bass experimentally infected by the intraperitoneal (i.p.) route in calculation of the median lethal dose. $7 \times 10^{4}$ pfu; $\mathbf{\square}: 7 \times 10^{3} \mathrm{pfu}_{i} \boldsymbol{\Delta}: 7 \times 10^{2} \mathrm{pfu}$; $\times: 7 \times 10^{1} \mathrm{pfu}_{\text {; }}$ *: 7 pfu; $0.7 \mathrm{pfu}_{i}+: 0.07 \mathrm{pfu}_{i}-$ : negative control

surrounded by serosanguinous ascitic fluid (Fig. 2e), and subserosal petechia was noted on all internal organs and visceral fat (Fig. 2e), while testes and ovarian tissues were swollen and reddened.

\section{Yellow perch Perca flavescens}

Initial mortalities occurred later than in largemouth bass with the first mortality noted from Days 10 to 12 p.i. at doses ranging from $7 \times 10^{7}$ to $7 \times 10^{3} \mathrm{pfu}$ (Fig. 3). With the exception of fish infected with $7 \times$ $10^{5} \mathrm{pfu}$, which reached a cumulative mortality of $40 \%$, fish infected with from $7 \times 10^{7}$ to $7 \times 10^{3}$ pfu displayed a maximum cumulative mortality of from 60 to $70 \%$. A decrease in the mortalities $(10 \%)$ was noted, beginning with the experimental group infected with $7 \times$ $10^{2} \mathrm{pfu}$, which did not experience its first and only incidence of mortality until Day 21 p.i. The lowest dose of 70 pfu caused no mortality. No mortality occurred in the negative control tanks. Calculation of an IP-LD 50 using the Reed \& Muench (1938) equation resulted in a value of $2.5 \times 10^{5} \mathrm{pfu}$ (Table 1 ).

Infected yellow perch exhibited pale gills, an erythematous protruded vent (Fig. 4a), intramuscular hemorrhages (Fig. 4b), and an accumulation of ascitic fluid. Severe hepatomegaly with irregular margination of the tissue was noted along with subcapsular petechial hemorrhages (not shown). The kidneys of yellow perch were normal in appearance on gross examination.

\section{Rainbow trout Oncorhynchus mykiss}

Fish inoculated at a dose of $7 \times 10^{7}$ pfu experienced the highest mortalities $(78 \%)$, with the majority of 

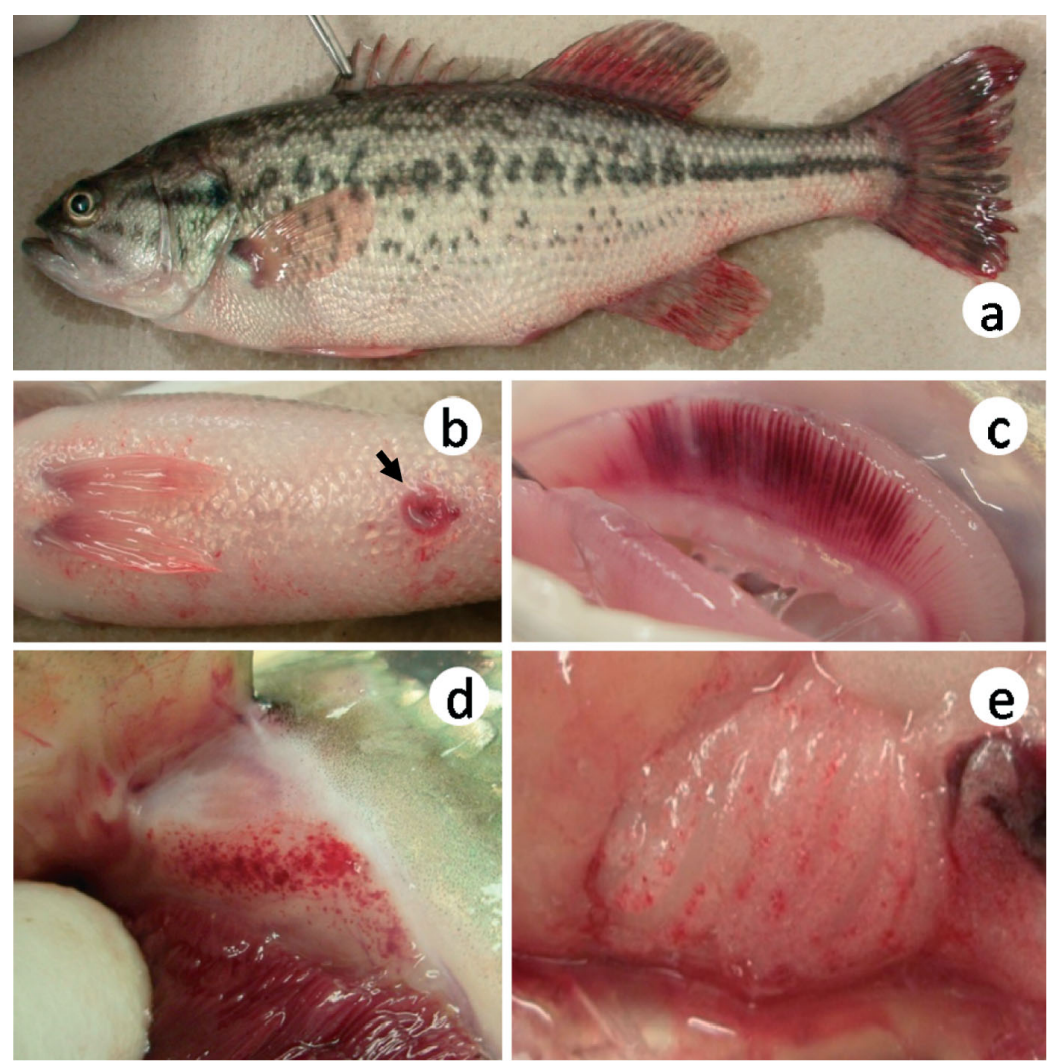

Fig. 2. Micropterus salmoides. Largemouth bass: (a) pronounced petechiation on all fins, (b) diffuse dermal erythema of the ventral abdomen with a reddened, thickened, and partially prolapsed vent (arrow), (c) focal areas of hemorrhage on gill arches surrounded by pale and whitened lamellae, (d) subdermal petechiation on the thymic regions at the dorsal insertion of the gill arch, and (e) subserosal petechia on all internal organs, especially on the pyloric caeca

groups experienced a maximum mortality between 20 and $30 \%$. Interestingly, the most rapid rates of mortality were observed between Days 8 and 14 p.i. The group of fish infected with 70 pfu was apparently healthy at the end of the study and did not record any mortality throughout the $28 \mathrm{~d}$ observation period. There were no mortalities noted in the control tank. The IP-LD ${ }_{50}$ calculation in accordance with the Reed \& Muench (1938) equation was $1.4 \times 10^{6}$ pfu (Table 1).

Despite mortality at higher doses, clinical signs were seldom seen. External lesions included mild to moderate subdermal petechial hemorrhages around the base of fins. Pronounced changes were also noted internally, with livers that were noticeably pale and friable with petechiation on the sub-serosal surface (Fig. 6a), splenomegaly, moderate to severe ecchymotic and petechial hemorrhages on the swimbladder wall, and intramuscular hemorrhaging (Fig. 6b).

\section{Brook trout Salvelinus fontinalis}

The highest mortality rate in brook trout did not occur at the highest level of inoculum delivered (Fig. 7).

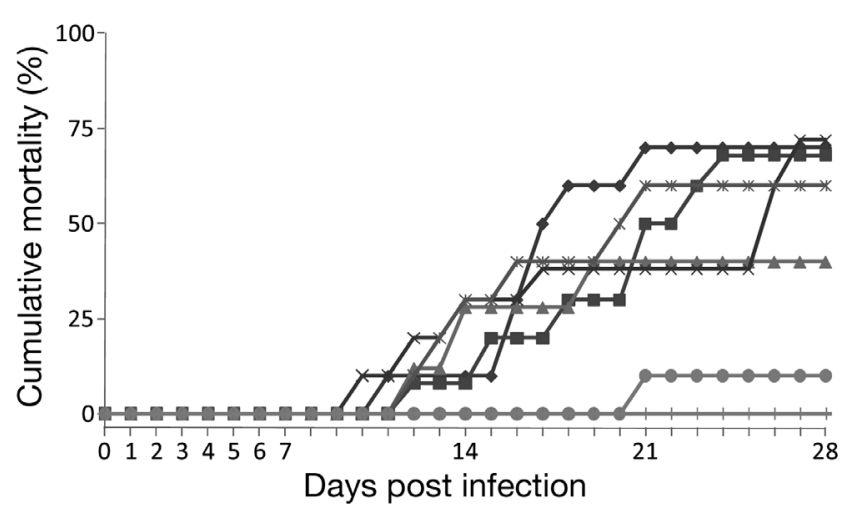

Fig. 3. Perca flavescens. Cumulative mortalities for yellow perch experimentally infected by the i.p. route in calculation of the median lethal dose. $\$ \times 10^{7} \mathrm{pfu}_{;} \mathbf{\square}: 7 \times 10^{6} \mathrm{pfu}_{\text {; }} \mathbf{\Delta}: 7 \times$ $10^{5} \mathrm{pfu}_{;} \times: 7 \times 10^{4} \mathrm{pfu}_{i} *: 7 \times 10^{3} \mathrm{pfu}_{i} \mathbf{0} 7 \times 10^{2} \mathrm{pfu}_{i}+: 70 \mathrm{pfu}$; -: negative control

deaths occurring between Day 8 and 11 p.i. (Fig. 5). The second highest mortality rate $(60 \%)$ occurred in fish infected with $7 \times 10^{4} \mathrm{pfu}$, with most of the deaths occurring between Day 11 and 20 p.i. The remaining
Fish injected with $7 \times 10^{3}$ pfu reached $50 \%$ mortality between Days 6 and 9 p.i. Unlike other groups, which reached a maximum mortality of from 30 to $40 \%$, the lower dosage appeared to be more lethal. The first incidence of mortality was noted at Day 3 p.i. in fish infected at the highest dose of $7 \times 10^{7} \mathrm{pfu}$, but only reached a maximum mortality of $30 \%$. Furthermore, the majority of deaths occurred between Days 5 and 14 p.i., which was a level similar to that observed in rainbow trout. The control tank did not experience any mortality throughout the duration of the experiment. Following the equation generated by Reed \& Muench (1938), the IP-LD 50 was $5 \times 10^{6} \mathrm{pfu}$ (Table 1).

External signs of disease were rarely noted. Conversely, internal lesions were in the form of pale, friable, and enlarged livers (Fig. 8). Severe petechiation and ecchymotic hemorrhages were diffusely scattered throughout adipose tissue surrounding the viscera (Fig. 8). Abdominal organs and viscera were remarkably wet on appearance, as a result of severe ascitic fluid accumulation. 


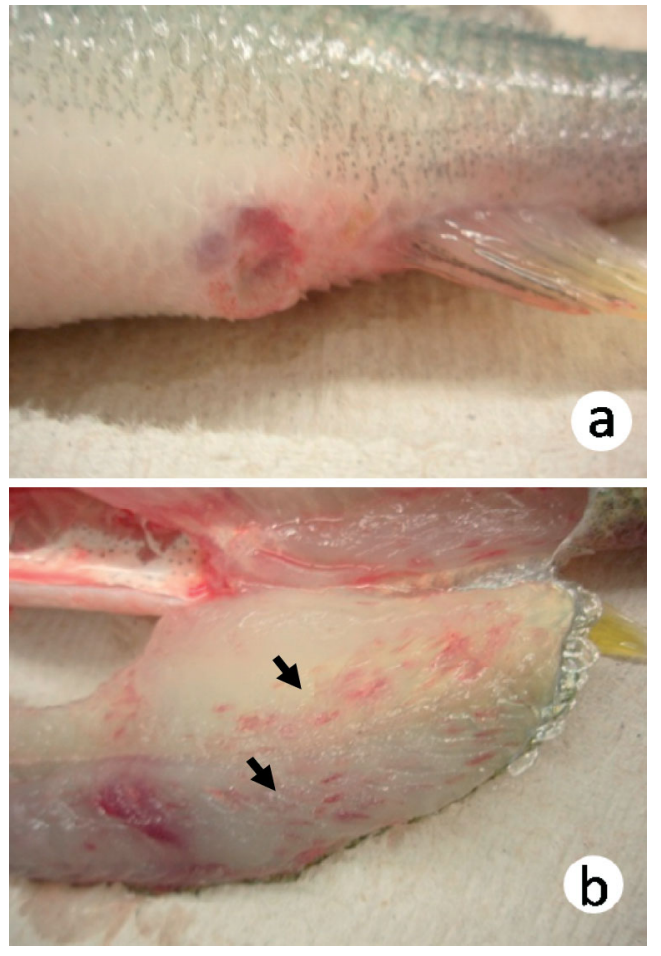

Fig. 4. Perca flavescens. Yellow perch: (a) erythematous vent surrounded by intramuscular hemorrhages and (b) transected lateral muscle tissue exhibiting diffuse multifocal intramuscular hemorrhages (arrows)

\section{Brown trout Salmo trutta}

Fish inoculated at the highest dose of $7 \times 10^{7} \mathrm{pfu}$ experienced the highest mortalities $(80 \%)$ and the earliest mortality, at Day 3 p.i. (Fig. 9). However, a constant rate of mortality was observed throughout the observed $28 \mathrm{~d}$. Unexpectedly, the second highest dose administered $\left(7 \times 10^{6} \mathrm{pfu}\right)$ achieved a maximum mortality rate of only $10 \%$, which occurred on Day 17 p.i. When comparing the doses that followed, a correlation between the days p.i. to first mortality and to the dose administered is evident. In the end, cumulative mortality rates did not clearly exhibit a correlation to the dosage administered. No mortalities were noted from the control tank throughout the $28 \mathrm{~d}$ period. In accordance with the Reed \& Muench (1938) equation, the IP-LD 50 was $5 \times 10^{6} \mathrm{pfu}$ (Table 1).

Clinical signs observed in brown trout were also mild when compared to other species. One fish that was inoculated with $7 \times 10^{2}$ pfu had peri-anal swelling and severely pale gills (Fig. 10). No internal lesions were noted.

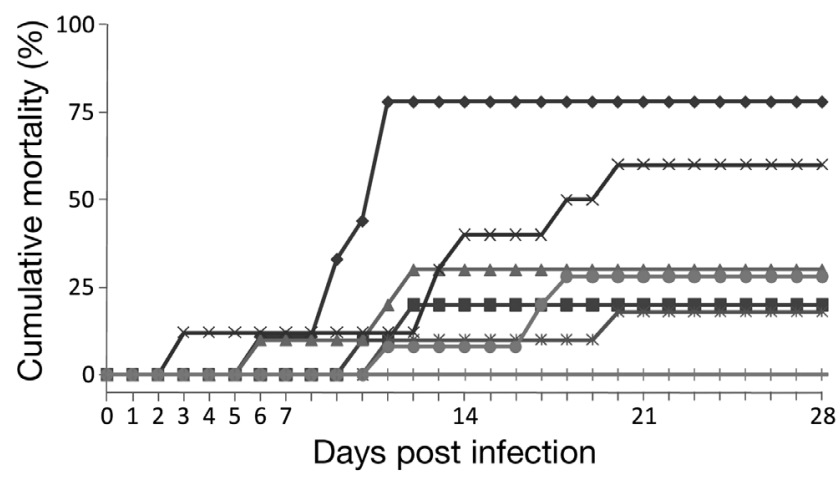

Fig. 5. Oncorhynchus mykiss. Cumulative mortalities for rainbow trout experimentally infected by the i.p. route in calculation of the median lethal dose. $7 \times 10^{7} \mathrm{pfu}_{\text {; }} \mathbf{\square}: 7 \times 10^{6} \mathrm{pfu}_{\text {; }}$

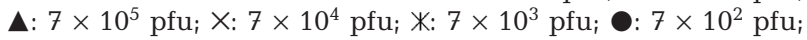
+: $70 \mathrm{pfu}_{\text {; }}-$ : negative control

\section{Chinook salmon Oncorhynchus tshawytscha}

Fish inoculated at a dose of $7 \times 10^{7}$ pfu had the highest cumulative mortality $(70 \%)$, with the majority of mortalities occurring between Days 5 and 12 p.i. (Fig. 11). When assessing the mortality data for the lower doses, cumulative mortality was from approximately 20 to $30 \%$, with the exception of groups infected with $7 \times 10^{5}$ and $7 \times 10^{4} \mathrm{pfu}$, which contained fish that were apparently healthy by the end of the $28 \mathrm{~d}$ observance period. No mortalities were noted in the control tank. Calculation of the Reed \& Muench (1938) equation resulted in a $\mathrm{LD}_{50}$ of $1.01 \times 10^{7}$ pfu (Table 1 ).

Profound external lesions were not noted upon gross examination. A few mortalities were, however, observed to have distended abdomens with palpable fluid contents (Fig. 12a). The suspicion of ascites was confirmed when samples of from approximately 500 to $1000 \mu \mathrm{l}$ of fluid were obtained from some individuals (Fig. 12b).
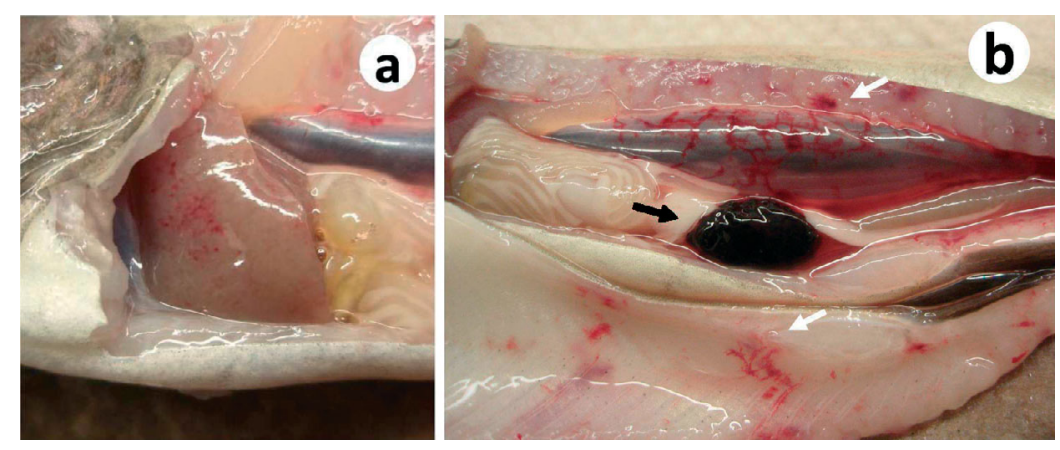

Fig. 6. Oncorhynchus mykiss. Rainbow trout: (a) pale, friable liver with subserosal petechiation and (b) severe splenomegaly (black arrow), with focal areas of intramuscular hemorrhaging in the abdominal wall and lateral musculature (white arrows) and petechia on the swimbladder 


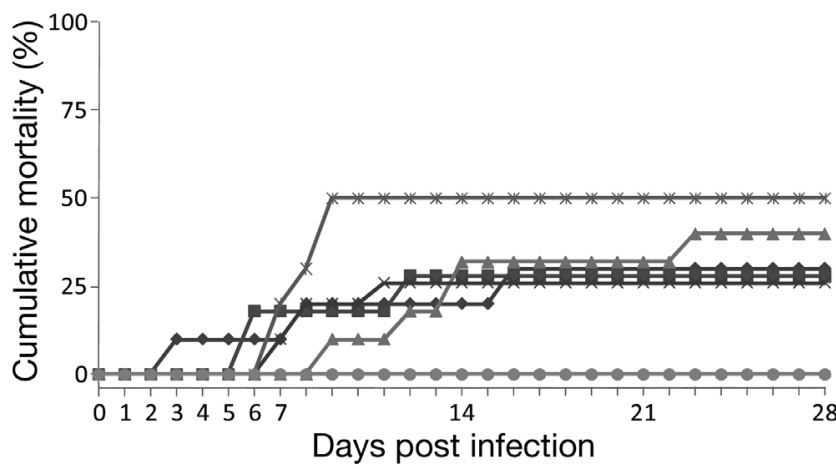

Fig. 7. Salvelinus fontinalis. Cumulative mortalities for brook trout experimentally infected by the i.p. route in calculation of the median lethal dose. $7 \times 10^{7}$ pfu; $\square: 7 \times 10^{6}$ pfu; $\boldsymbol{\Delta}: 7 \times$

$10^{5} \mathrm{pfu}_{;} \times: 7 \times 10^{4} \mathrm{pfu} ; *: 7 \times 10^{3} \mathrm{pfu} ;$ : negative control

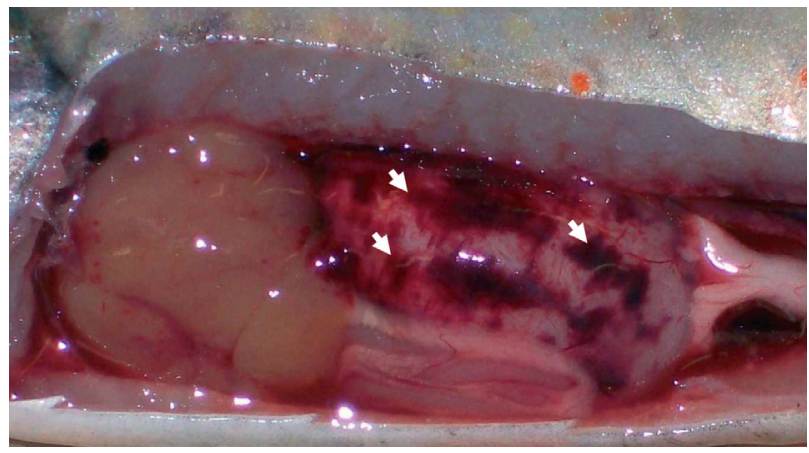

Fig. 8. Salvelinus fontinalis. Brook trout: livers were markedly pale, friable, and enlarged. Severe petechiation and ecchymotic hemorrhages were diffusely scattered throughout adipose tissue surrounding the viscera (arrows)

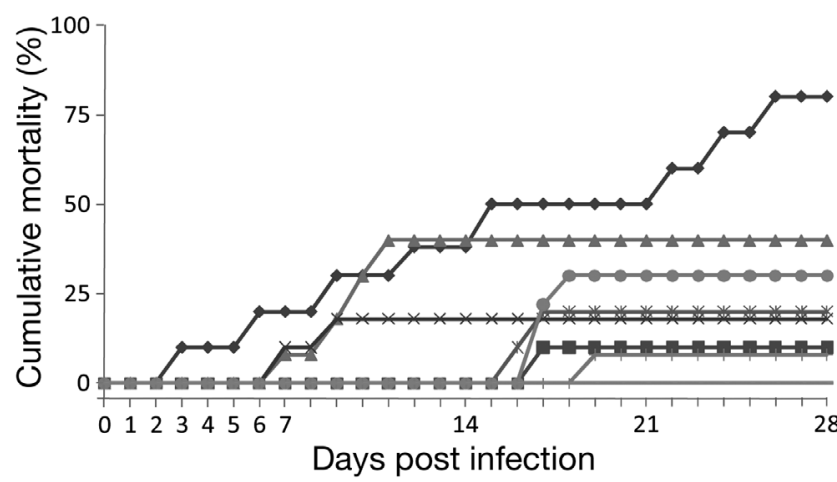

Fig. 9. Salmo trutta. Cumulative mortalities for brown trout experimentally infected by the i.p. route in calculation of the median lethal dose. $\$ \times 10^{7}$ pfu; $\mathbf{\square}: 7 \times 10^{6} \mathrm{pfu}_{;} \boldsymbol{\Delta}: 7 \times$ $10^{5} \mathrm{pfu}_{;} \times: 7 \times 10^{4} \mathrm{pfu}_{;} *: 7 \times 10^{3} \mathrm{pfu} ; \mathbf{0 :} 7 \times 10^{2} \mathrm{pfu}_{;}+: 70 \mathrm{pfu}$;

$$
\text { -: negative control }
$$

\section{Coho salmon Oncorhynchus kisutch}

Overall, only $10 \%$ cumulative mortality was noted for each dose of from $7 \times 10^{7}$ and $7 \times 10^{5}$ pfu on Days 22

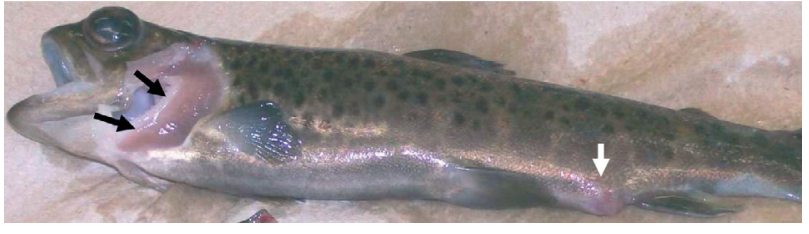

Fig. 10. Salmo trutta. Brown trout: external signs of disease were mild. This particular fish was inoculated with $7 \times 10^{2}$ pfu and had peri-anal swelling (white arrow) and severely pale gills (black arrows)

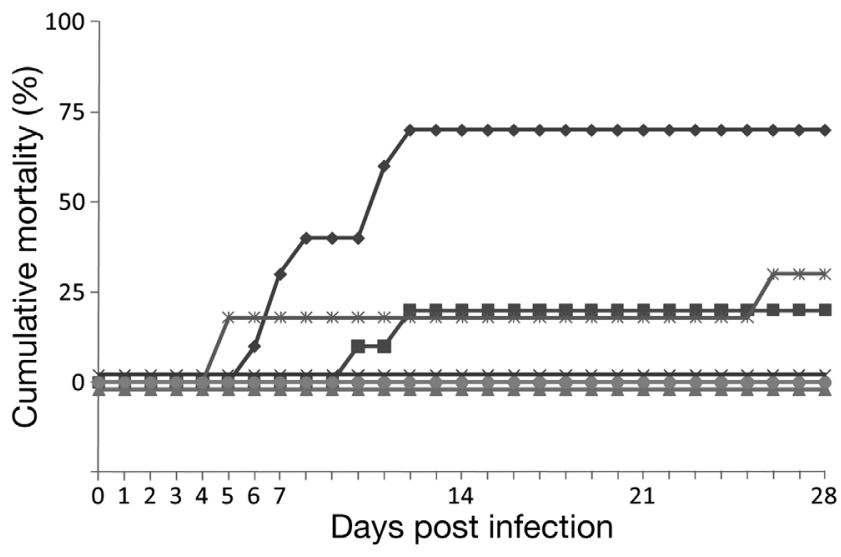

Fig. 11. Oncorhynchus tshawytscha. Cumulative mortalities for chinook salmon experimentally infected by the i.p. route in calculation of the median lethal dose. $7 \times 10^{7} \mathrm{pfu}$; 口: $7 \times 10^{6} \mathrm{pfu}_{;} \mathbf{\Delta}: 7 \times 10^{5} \mathrm{pfu}_{\text {; }} \times: 7 \times 10^{4} \mathrm{pfu}_{i} *: 7 \times 10^{3} \mathrm{pfu}$; -: negative control

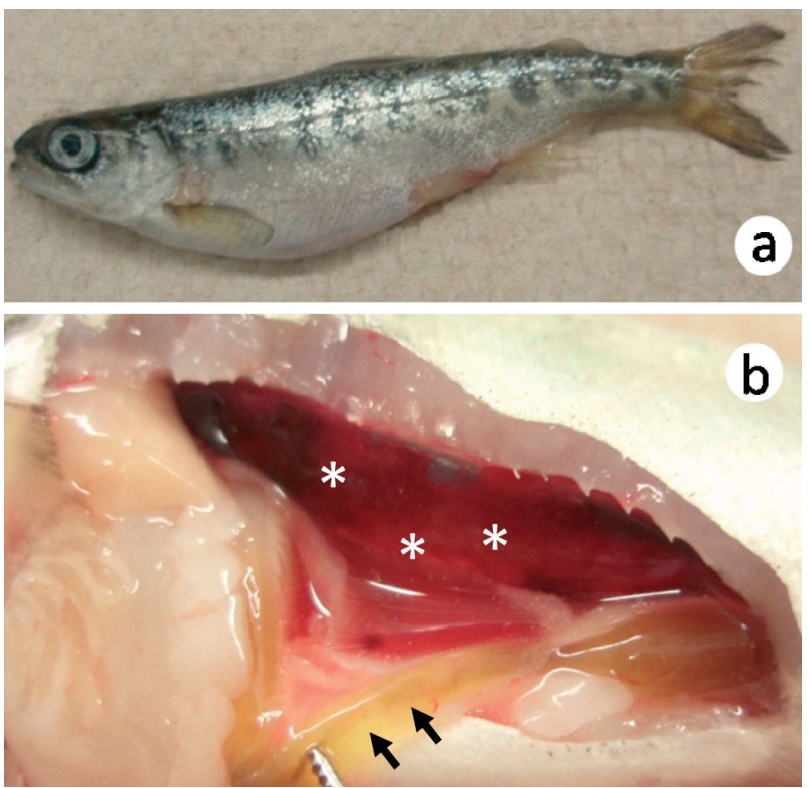

Fig. 12. Oncorhynchus tshawytscha. Chinook salmon: (a) distention of the abdomen with palpable fluid contents, suggestive of ascites, and (b) serosanguinous fluid (asterisks) in the peritoneal space. Note the fluid-filled intestines (arrows) 
and 7 p.i., respectively (Fig. 13). All other doses used in the present experiment did not result in mortality. No mortalities were noted in the control tank. As a result of being unable to obtain mortalities above and below $50 \%$, the IP-LD 50 value was estimated to be greater than the highest administered dose of $>7 \times 10^{7} \mathrm{pfu}$. One mortality was noticeably emaciated, with caudal fin erosion and necrosis.

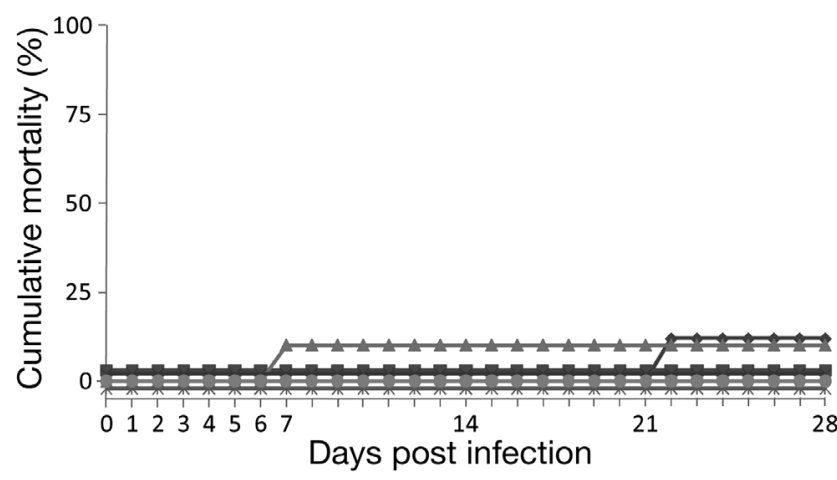

Fig. 13. Oncorhynchus kisutch. Cumulative mortalities for coho salmon experimentally infected by the i.p. route in calculation of the median lethal dose. $\bullet \times 10^{7}$ pfu; $\mathbf{\square}: 7 \times$ $10^{6}$ pfu; $\mathbf{\Delta}: 7 \times 10^{5} \mathrm{pfu}_{;} \times: 7 \times 10^{4} \mathrm{pfu} ; *: 7 \times 10^{3} \mathrm{pfu}_{\text {; }}$ : negative control
Kidney and spleen samples from mortalities of all species were confirmed for the presence of VHSV by cell culture, and the identity of the isolated virus was confirmed by RT-PCR.

\section{Histopathologic analysis}

Microscopic lesions were identical in VHSV-moribund fish of the 7 species. The severity, however, varied from one fish to another. In the case of largemouth bass, histological sections of the fins revealed diffuse congestion and multifocal hemorrhage of all fins that were sampled (Fig. 14a). Profound changes were noted in submitted gill tissues, which often displayed marked congestion in the primary lamellar spaces (Fig. 14b). Splenic tissue was markedly congested with focal areas of erythrocyte accumulation (Fig. 14c). The ovarian tissue exhibited diffuse congestion and severe hemorrhaging throughout the interstitium (Fig. 14d). The anterior kidneys exhibited marked lymphoid depletion in most fish.

Histopathology was demonstrated in the yellow perch in the form of subcutaneous hemorrhage, edema, and congestion between the dermis and subcutaneous tissue (Fig. 15a), with interstitial hemor-
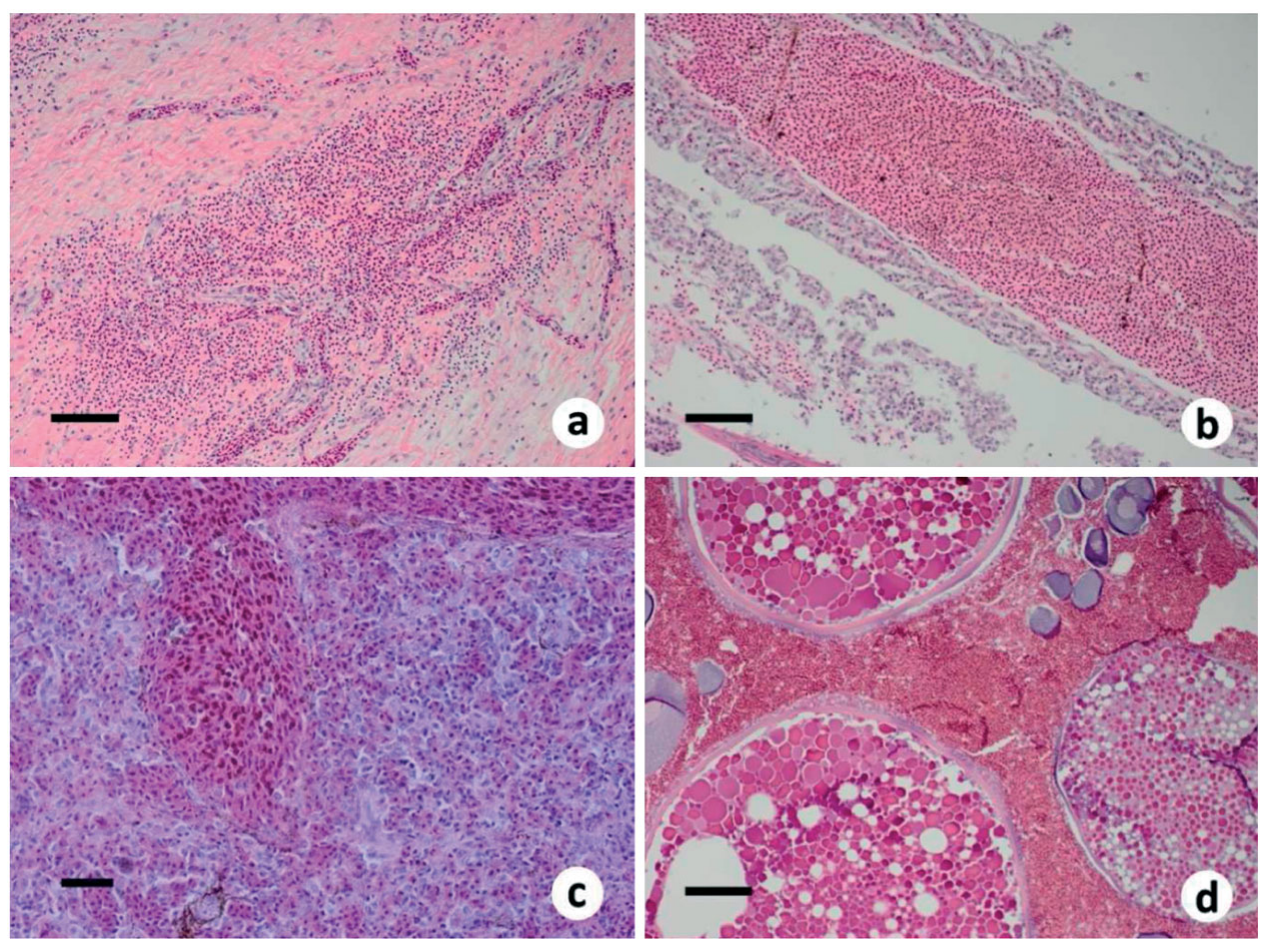

Fig. 14. Micropterus salmoides. Histopathology of largemouth bass revealed: (a) diffuse congestion and multifocal hemorrhaging in all fin sections (scale bar $=200 \mu \mathrm{m}$ ), (b) severe congestion in the primary lamellar vessel (scale bar $=200 \mu \mathrm{m})$, (c) severe congestion and lymphoid depletion of the spleen (scale bar $=100 \mu \mathrm{m}$ ), and $(\mathrm{d})$ ovarian tissues displayed marked congestion between ova and severe hemorrhaging throughout the interstitium (scale bar $=400 \mu \mathrm{m})$; hematoxylin and eosin staining 

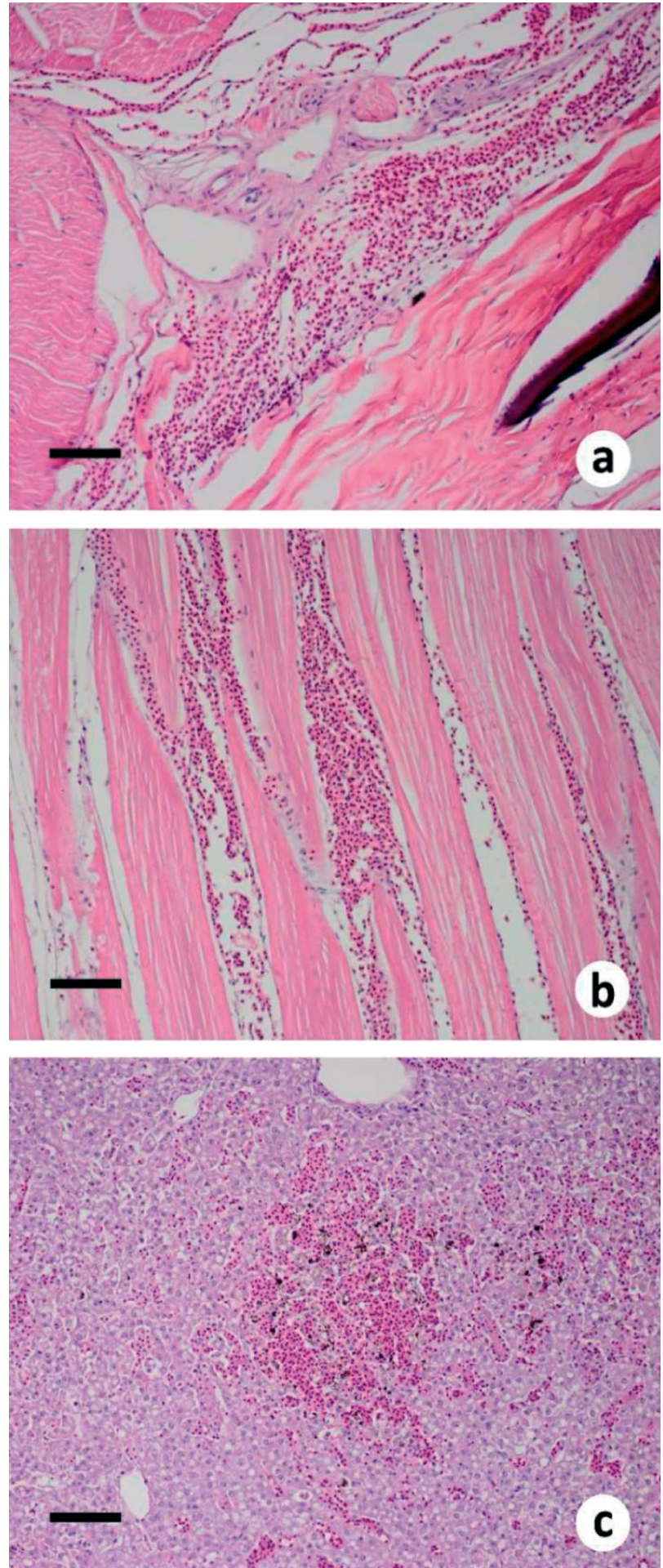

Fig. 15. Perca flavescens. Histopathology of yellow perch demonstrated: (a) subcutaneous hemorrhage, edema, and congestion in the hypodermis (scale bar $=200 \mu \mathrm{m}$ ) with additional (b) interstitial hemorrhage between myofibers (scale bar $=200 \mu \mathrm{m}$ ), (c) the liver tissue displayed marked multifocal degeneration, necrosis, vacuolation of hepatocytes, and localized areas of congestion and hemorrhage (scale bar = $200 \mu \mathrm{m})$; hematoxylin and eosin staining
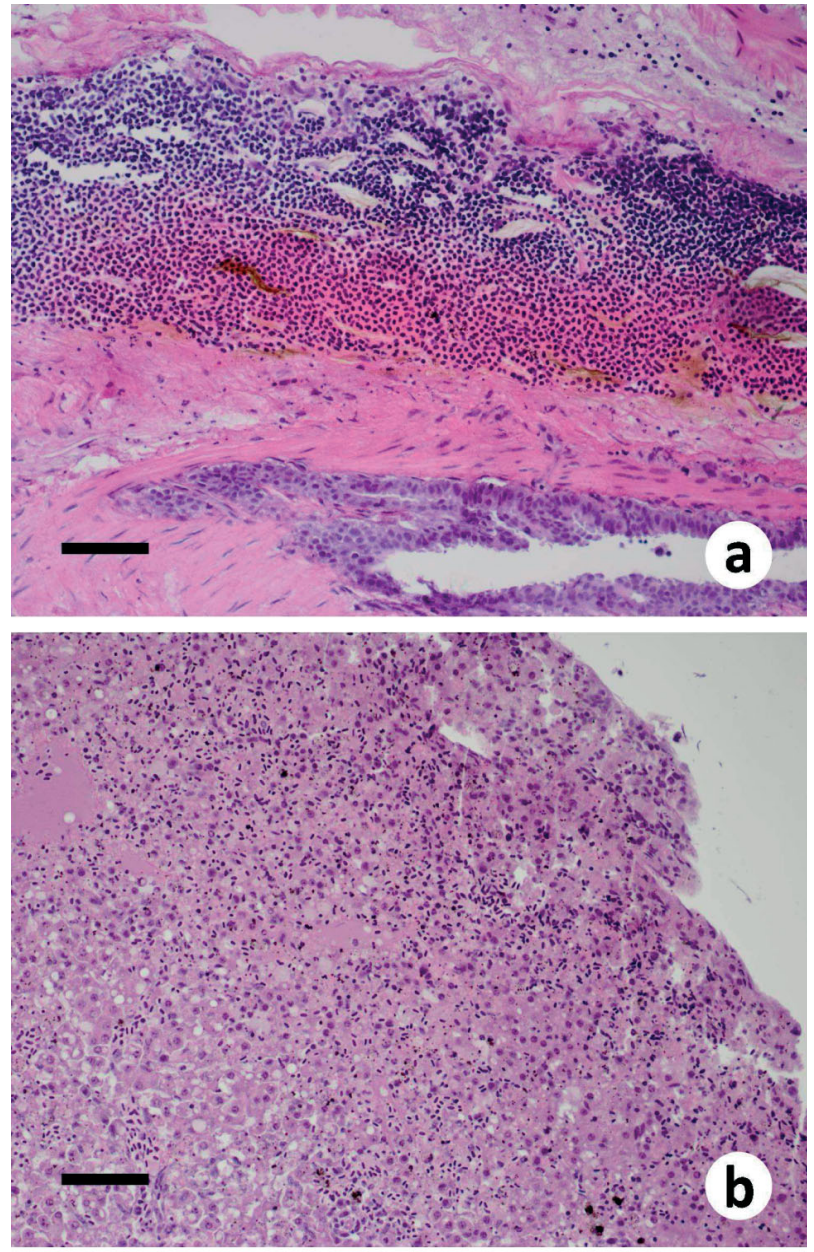

Fig. 16. Oncorhynchus mykiss. Histopathology of rainbow trout displayed: (a) massive hemorrhages in the swimbladder wall (scale bar $=200 \mu \mathrm{m}$ ) and $(\mathrm{b})$ moderate congestion and mild vacuolation of some hepatocytes in the liver (scale bar $=$ $200 \mu \mathrm{m})$; hematoxylin and eosin staining

rhage between myofibers in deeper skeletal muscle fibers (Fig. 15b). The liver exhibited marked multifocal necrosis, vacuolation of hepatocytes, and localized areas of congestion (Fig. 15c).

All salmonids showed significantly less pathological changes in comparison to those observed in the largemouth bass or the yellow perch. The swimbladders of the rainbow trout displayed multifocal hemorrhages in the outer wall (Fig. 16a), while the swimbladders of brook trout and brown trout exhibited massive hemorrhages, primarily in the surrounding connective tissue. Rainbow trout livers often demonstrated multifocal areas of necrosis and degeneration, with vacuolation of hepatocytes containing pyknotic nuclei (Fig. 16b), which was similarly noted in the brook trout. Kidneys were not examined microscopically. 


\section{DISCUSSION}

The generated data from the present study confirmed a wide range of fish hosts susceptible to VHSV$\mathrm{IVb}$ and suggest that cool water fish species are probably more susceptible to VHSV-IVb than salmonid species. The largemouth bass Micropterus salmoides were by far the most susceptible, followed by the yellow perch Perca flavescens, which required a higher viral dose to reach the IP- $\mathrm{LD}_{50}$. Salmonids required a dose several orders of magnitude higher to reach the median lethal dose, which also resulted in fewer mortalities overall. The cool water species exhibited clinical signs consistent with VHSV (as reviewed in Wolf 1988), suffered varying degrees of mortality, and succumbed to death by VHSV. The virus was recovered from the internal organs of affected fish by cell culture, and its identity was confirmed by RT-PCR. These findings, together with our previous study on muskellunge Esox masquinongy (Kim \& Faisal 2010), fulfill Rivers' (1937) postulates for the mortalities observed in a number of fish species in the Laurentian Great Lakes basin (Elsayed et al. 2006, Gagné et al. 2007, Groocock et al. 2007, Lumsden et al. 2007). The findings of the present study also confirm the original field observations that VHSV-IVb has a relatively wide host range.

Most of the data on the host range and fish species susceptibility of the North American VHSV-IVa was obtained from moribund fish during mortality episodes or from apparently healthy fish during routine health inspections. A limited number of experimental infection studies using VHSV-IVa isolates have been performed. Results indicated that VHSV-IVa is highly pathogenic to the Pacific herring Clupea pallasii (Kocan et al. 1997, Hershberger et al. 2007), moderately pathogenic to the Pacific sardine Sardinops sagax (Arkush et al. 2006), and of minimal pathogenicity to rainbow trout Oncorhynchus mykiss (Winton et al. 1991, Follett et al. 1997). Our results with VHSV-IVb indicate a similar trend, with clear differences noted between pathogenicity in cool water species and cold water species. From the time to death, percent cumulative mortality, and the severity of exhibited clinical signs data, the largemouth bass and muskellunge (Kim \& Faisal 2010) were more affected by VHSV-IVb, as confirmed by the low IP-LD 50 values. Most interesting was the fact that the muskellunge IP- $\mathrm{LD}_{50}$ was $2.2 \mathrm{pfu}$ (authors' unpubl. data), which was lower than that affecting largemouth bass. It was evident from the mortality and morbidity data that coho Oncorhynchus kisutch and chinook salmon $O$. tshawytscha were the least affected. Indeed, field observations indicated that these 2 species do not exhibit clinical signs, even though VHSV-IVb was isolated from them (M. Faisal unpubl. data). The lack of clinical signs and low susceptibility of brown trout
Salmo trutta in the present study were corroborated through the field studies by Gagné et al. (2007) with the VHSV-IVb isolate and through experimental infections studied by Jørgensen (1980), who demonstrated that brown trout were susceptible to VHSV-I isolates only at high concentrations via immersion challenge.

In all of the 7 fish species trials, some fish survived VHSV-IVb exposure throughout the observation period and beyond. These survivors were suspected to be carriers of VHSV, but this was not confirmed in the present study. The potential for shedding p.i. has been suggested in previous experimental infections with VHSV (Jørgensen 1980, Meier \& Jørgensen 1980), demonstrated in Pacific herring (Kocan et al. 1997), and is the basis for which cohabitation infection trials have been conducted with turbot Psetta maxima (López-Vázquez et al. 2007), Japanese flounder Paralichthys olivaceus (Muroga et al. 2004), and Atlantic halibut Hippoglossus hippoglossus (Bowden 2003). The ability of fish to become carriers and active shedders was recently shown in experimentally infected salmonids that were held in tanks for 9 mo following infection (M. Faisal \& M. Shavalier pers. comm.). Others have also commented on the ability of VHSVinfected fish to shed virus and become sources of infections leading to epizootic mortality (reviewed in Wolf 1988). These data are alarming given the prevalence of salmonid species that are resident to the Great Lakes and are commonly raised in hatchery settings for stocking. If VHSV-IVb should gain access to hatchery facilities, there may be a risk of producing 'natural' reservoirs for VHSV throughout the Great Lakes, thereby jeopardizing conservation efforts. Future studies will require that the shedding potential and carrier status of salmonids be evaluated.

Clinical signs and internal lesions observed in the present study were predominantly similar in cool water fish species that experienced morbidity, with hemorrhages being the most prominent sign. The hemorrhage was often so intense that portions of the gills became white in color, a finding consistent with localized ischemia (Fig. 2). Damage to capillary and sinusoid endothelia leading to hemorrhages has been previously demonstrated (de Kinkelin et al. 1979, Evensen et al. 1994). In the present study, the intensity of hemorrhages varied from one species to another, with largemouth bass showing the most external and internal hemorrhages. Surprisingly, the largemouth bass was the only species to show congestion of the kidneys, but histopathology was not as severe compared to that of the muskellunge. It seems that severity of hemorrhaging depends on the susceptibility of capillary endothelium, which varies from one fish species to another. Studies performed on other VHSV strains have shown that, while hemorrhages are less obvious in the Pacific herring with VHSV-IVa 
(Kocan et al. 1997), they were most obvious in rainbow trout (Neukirch 1984), pike Esox lucius (Meier \& Jørgensen 1980), sea bass Dicentrarchus labrax, and turbot Scophthalmus maximus (Castric \& de Kinkelin 1984). Also in the present study, no skin lesions, such as those observed with VHSV-infected Pacific herring (Meyers et al. 1994), Pacific cod Gadus macrocephalus and hake Merluccrus productus (Smail 2000), were observed in VHSV-IVb-infected fish.

Gross and histological lesions predominated in cool water species, in comparison to the cold water species examined. While largemouth bass and yellow perch demonstrated intramuscular hemorrhages, fin hemorrhages, severely pale gills, hemorrhages in gonadal tissue, and ascites, the salmonids rarely exhibited such signs. These changes were probably due to a number of factors, which include increased permeability of blood vessels, decreased clotting mechanisms, virus production in endothelium, and/or increased red cell fragility or intravascular hemolysis. The integrity of endothelial cells in the swimbladder of salmonids may also have been more vulnerable to VHSV, since hemorrhage and congestion in the swimbladder wall and connective tissue were a common finding amongst salmonids. While gross lesions and histopathology varied between cool and cold water species in our study, some have suggested experimentally infected nonsalmonids and salmonids with VHSV-I isolates demonstrate similar lesions (Meier \& Jørgensen 1980). The relationship between species type, virus genotype used, and lesions observed is unclear at this time and will require further study to determine whether a correlation exists.

In conclusion, the present study fulfills Rivers' (1937) postulates and also provides solid evidence that deadly tissue alternations caused by VHSV IVb were responsible for fish mortality episodes that occurred in the Great Lakes basin (2002 to 2008). The present study also provides evidence that juvenile fish are susceptible to the infection. This is surprising since, in the midst of mortality episodes, adult, sexually mature fish were the only class found. Further studies are in progress to determine the interactions of each fish species with VHSV-IVb. These differences in susceptibility between cool and cold water species, although determined in a laboratory setting, may offer clues as to why VHSV-IVb is not commonly isolated from clinically affected salmonid species.

\section{LITERATURE CITED}

American Fisheries Society-Fish Health Section (2007) FHS blue book: suggested procedures for the detection and identification of certain finfish and shellfish pathogens, 2007 edn. AFS-FHS, Bethesda, MA
Arkush KD, Mendonca HL, McBride AM, Yun S, McDowell TS, Hedrick RP (2006) Effects of temperature on infectivity and of commercial freezing on survival of the North American strain of viral haemorrhagic septicaemia virus (VHSV). Dis Aquat Org 69:145-151

Batts WN, Winton JR (1989) Enhanced detection of infectious hematopoietic necrosis virus and other fish viruses by pretreatment of cell monolayers with polyethylene glycol. J Aquat Anim Health 1:284-290

Batts WN, Traxler GS, Winton JR (1991) Factors affecting the efficiency of plating for selected fish rhabdoviruses. In: Fryer JL (ed) Proceedings of the 2nd international symposium on viruses of lower vertebrates. Oregon State University Press, Corvallis, OR, p 17-24

Benmansour A, Basurco B, Monnier AF, Vende P, Winton JR, de Kinkelin P (1997) Sequence variation of the glycoprotein gene identifies three distinct lineages within field isolates of viral haemorrhagic septicaemia virus, a fish rhabdovirus. J Gen Virol 78:2837-2846

> Bowden TJ (2003) A study of susceptibility of Atlantic halibut, Hippoglossus hippoglossus (L.), to viral haemorrhagic septicaemia virus isolated from turbot, Scophthalmus maximus (L.). J Fish Dis 26:207-212

Brunson R, True K, Yancy J (1989) VHS virus isolated at Makah National Fish Hatchery. Am Fish Soc Fish Health Newsl 17:3-4

> Byon JY, Tomakazu T, Hirono I, Aoki T (2006) Genome analysis of viral haemorrhagic septicaemia virus isolated from Japanese flounder Paralichthys olivaceus in Japan. Fish Sci 72:906-908

Castric J, de Kinkelin P (1984) Experimental study of the susceptibility of two marine fish species, sea bass (Dicentrarchus labrax) and turbot (Scophthalmus maximus), to viral haemorrhagic septicaemia. Aquaculture 41:203-212

de Kinkelin P, Chilmonczyck S, Dorson M, Le Berre M, Baudouy AM (1979) Some pathogenic facets of rhabdoviral infection of salmonid fish. In: Karger S (ed) Munich symposia on microbiology: mechanisms of viral pathogenesis and virulence. WHO Collaborating Centre, P. A. Bachmann, Munich, p 357-375

> Dixon PF, Feist S, Kehoe E, Parry L, Stone DM, Way K (1997) Isolation of viral haemorrhagic septicaemia virus from Atlantic herring Clupea harengus from the English Channel. Dis Aquat Org 30:81-89

> Einer-Jensen K, Ahrens P, Forsberg R, Lorenzen N (2004) Evolution of the fish rhabdovirus viral haemorrhagic septicaemia virus. J Gen Virol 85:1167-1179

> Einer-Jensen K, Ahrens P, Lorenzen N (2005) Parallel phylogenetic analyses using the N, G or Nv gene from a fixed group of VHSV isolates reveal the same overall genetic typing. Dis Aquat Org 67:39-45

> Elsayed E, Faisal M, Thomas M, Whelan G, Batts W, Winton J (2006) Isolation of viral haemorrhagic septicaemia virus from muskellunge, Esox masquinongy (Mitchill), in Lake St. Clair, Michigan, USA reveals a new sublineage of the North American genotype. J Fish Dis 29:611-619

> Evensen O, Meier W, Wahli T, Olesen NJ, Jørgensen PEV, Hastein $\mathrm{T}$ (1994) Comparison of immunohistochemistry and virus cultivation for detection of viral haemorrhagic septicaemia virus in experimentally infected rainbow trout Oncorhynchus mykiss. Dis Aquat Org 20:101-109

> Fijan N, Sulimanovic D, Bearzotti M, Muzinic D and others (1983) Some properties of the epithelioma papulosum cyprini (EPC) cell line from carp Cyprinus carpio. Ann Virol Inst Pasteur 134:207-220

> Follett J, Meyers TR, Burton T, Geesin J (1997) Comparative susceptibility of salmonid species in Alaska to infectious 
hematopoietic necrosis virus (IHNV) and North American viral hemorrhagic septicemia virus (VHSV). J Aquat Anim Health 9:34-40

Gagné N, Mackinnon AM, Boston L, Souter B, Cook-Versloot M, Griffiths S, Olivier G (2007) Isolation of viral haemorrhagic septicaemia virus from mummichog, stickleback, striped bass and brown trout in eastern Canada. J Fish Dis 30:213-223

Groocock GH, Getchell RG, Wooster GA, Britt KL and others (2007) Detection of viral hemorrhagic septicemia in round gobies in New York State (USA) waters of Lake Ontario and the St. Lawrence River. Dis Aquat Org 76:187-192

Hedrick RP, Batts WN, Yun S, Traxler GS, Kaufman J, Winton JR (2003) Host and geographic range extensions of the North American strain of viral hemorrhagic septicemia virus. Dis Aquat Org 55:211-220

Hershberger PK, Gregg J, Pacheco C, Winton J, Richard J, Traxler G (2007) Larval Pacific herring, Clupea pallasii (Valenciennes), are highly susceptible to viral haemorrhagic septicaemia and survivors are partially protected after their metamorphosis to juveniles. J Fish Dis 30: $445-458$

Hopper K (1989) The isolation of VHSV from chinook salmon at Glenwood Springs, Orcas Island, Washington. Am Fish Soc Fish Health Newsl 17:1

Jensen MH (1963) Preparation of fish tissue cultures for virus research. Bull Off Int Epizoot 59:131-134

Jørgensen PEV (1980) Egtved virus: the susceptibility of brown trout and rainbow trout to eight virus isolates and the significance of the findings for the VHS control. In: Ahne W (ed) Fish diseases. Springer-Verlag, Berlin, p 3-7

Kim R, Faisal M (2010) Experimental studies confirm the wide host range of the Great Lakes viral haemorrhagic septicaemia virus genotype IVb. J Fish Dis 33:83-88

Kim SM, Lee JI, Hong MJ, Park HS, Park SI (2003) Genetic relationship of the VHSV (viral hemorrhagic septicemia virus) isolated from cultured olive flounder, Paralichthys olivaceus in Korea. J Fish Pathol 16:1-12

Kocan R, Bradley M, Elder N, Meyers T, Batts B, Winton J (1997) North American strain of viral haemorrhagic septicaemia virus is highly pathogenic for laboratory-reared Pacific herring. J Aquat Anim Health 9:279-290

López-Vázquez C, Dopazo CP, Barja JL, Bandín I (2007) Experimental infection of turbot, Psetta maxima (L.), with strains of viral haemorrhagic septicaemia virus isolated from wild and farmed marine fish. J Fish Dis 30:303-312

Lumsden JS, Morrison B, Yason C, Russell S and others (2007) Mortality event in freshwater drum (Aplodinotus grunniens) from Lake Ontario, Canada associated with viral hemorrhagic septicemia virus, type IV. Dis Aquat Org 76: 99-111

Meier W, Jørgensen PEV (1980) Isolation of VHS virus from pike (Esox lucius L.) with hemorrhagic symptoms. In: Ahne W (ed) Fish diseases. Springer-Verlag, Berlin, p 8-17

Meyers TR, Sullivan J, Emmenegger E, Follett J, Short S, Batts WN, Winton JR (1992) Identification of viral hemorrhagic septicemia virus isolated from Pacific cod Gadus macrocephalus in Prince William Sound, Alaska, USA. Dis Aquat Org 12:167-175

Meyers TR, Short S, Lipson K, Batts WN, Winton JR, Wilcock J, Brown E (1994) Association of viral hemorrhagic septicemia virus with epizootic hemorrhages of the skin in Pacific herring Clupea harengus pallasi from Prince
William Sound and Kodiak Island, Alaska, USA. Dis Aquat Org 19:27-37

Meyers TR, Short S, Lipson K (1999) Isolation of the North American strain of viral hemorrhagic septicemia virus (VHSV) associated with epizootic mortality in two new host species of Alaskan marine fish. Dis Aquat Org 38: 81-86

Mortensen HF, Heuer OE, Lorenzen N, Otte L, Olesen NJ (1999) Isolation of viral haemorrhagic septicaemia virus (VHSV) from wild marine fish species in the Baltic Sea, Kattegat, Skagerrak and the North Sea. Virus Res 63: 95-106

Muroga K, Iida H, Mori K, Nishizawa T, Arimoto M (2004) Experimental horizontal transmission of viral hemorrhagic septicemia virus (VHSV) in Japanese flounder Paralichthys olivaceus. Dis Aquat Org 58:111-115

Neukirch M (1984) An experimental study of the entry and multiplication of viral haemorrhagic septicaemia virus in rainbow trout, Salmo gairdneri Richardson, after waterborne infection. J Fish Dis 7:231-234

Office International des Epizooties (2006) Manual of diagnostic tests for aquatic animals, 5th edn. Office International des Epizooties, Paris

Prophet E, Mills B, Arrington J, Sobin LH (1992) Laboratory methods in histotechnology. Armed Forces Institute of Pathology, American Registry of Pathology, Washington, DC

Reed LJ, Muench H (1938) A simple method of estimating fifty per cent endpoints. Am J Hyg 27:493-497

- Rivers TM (1937) Viruses and Koch's postulates. J Bacteriol 33:1-12

Schäperclaus W (1938) Die Schädigungen der deutschen Fischerei durch Fischparasiten und Fischkrankheiten. Allg Fischztg 41:256-259, 267-270

Smail DA (2000) Isolation and identification of viral haemorrhagic septicaemia (VHS) viruses from cod Gadus morhua with the ulcus syndrome and from haddock Melanogrammus aeglefinus having skin haemorrhages in the North Sea. Dis Aquat Org 41:231-235

Snow M, Cunningham CO, Melvin WT, Kurath G (1999) Analysis of the nucleoprotein gene identifies distinct lineages of viral haemorrhagic septicaemia virus within the European marine environment. Virus Res 63:35-44

Snow M, Bain N, Black J, Taupin V and others (2004) Genetic population structure of marine viral haemorrhagic septicaemia virus (VHSV). Dis Aquat Org 61:11-21

Tordo N, Benmansour A, Calisher C, Dietzgen RG and others (2005) Family Rhabdoviridae. In: Fauquet CM, Mayo MA, Maniloff J, Desselberger U, Ball LA (eds) Virus taxonomy. Academic Press, London, p 635-644

Traxler G, Kieser D, Evelyn TPT (1995) Isolation of North American strain of VHS virus from farmed Atlantic salmon. In: Margolis L (ed) Aquaculture Update No. 72. Aquaculture Division Pacific Biological Station, Nanaimo, $\mathrm{BC}$

Winton JR, Batts WN, Deering RE, Brunson R, Hopper K, Nishizawa T, Stehr C (1991) Characteristics of the first North American isolates of viral hemorrhagic septicemia virus. In: Fryer JL (ed) Proceedings of the 2nd international symposium on viruses of lower vertebrates. Oregon State University Press, Corvallis, OR, p 43-50

Wolf K (1988) Viral hemorrhagic septicemia. In: Wolf K (ed) Fish viruses and fish viral diseases. Cornell University Press, Ithaca, NY, p 217-249

Submitted: August 27, 2009; Accepted: February 23, 2010 Proofs received from author(s): July 6, 2010 